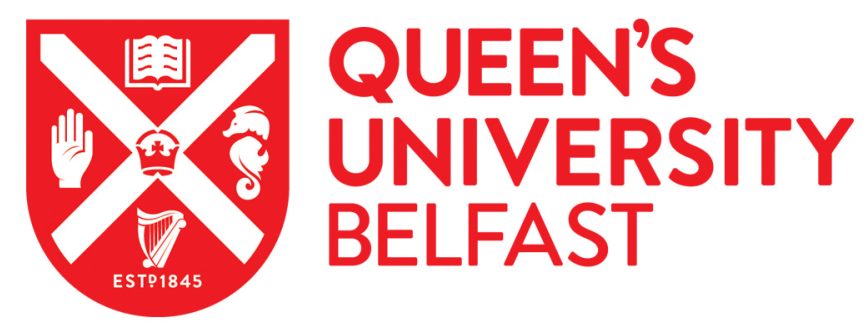

\title{
Influence of root zone nitrogen management and a summer catch crop on cucumber yield and soil mineral nitrogen dynamics in intensive production systems
}

Guo, R. Y., Li, X. L., Christie, P., Chen, Q., Jiang, R. F., \& Zhang, F. S. (2008). Influence of root zone nitrogen management and a summer catch crop on cucumber yield and soil mineral nitrogen dynamics in intensive production systems. Plant and Soil, 313(1-2), 55-70. https://doi.org/10.1007/s11104-008-9679-0

Published in:

Plant and Soil

Queen's University Belfast - Research Portal:

Link to publication record in Queen's University Belfast Research Portal

\section{General rights}

Copyright for the publications made accessible via the Queen's University Belfast Research Portal is retained by the author(s) and / or other copyright owners and it is a condition of accessing these publications that users recognise and abide by the legal requirements associated with these rights.

Take down policy

The Research Portal is Queen's institutional repository that provides access to Queen's research output. Every effort has been made to ensure that content in the Research Portal does not infringe any person's rights, or applicable UK laws. If you discover content in the Research Portal that you believe breaches copyright or violates any law, please contact openaccess@qub.ac.uk. 


\title{
Influence of root zone nitrogen management and a summer catch crop on cucumber yield and soil mineral nitrogen dynamics in intensive production systems
}

\author{
Ruiying Guo • Xiaolin Li • Peter Christie • \\ Qing Chen $\cdot$ Rongfeng Jiang $\cdot$ Fusuo Zhang
}

Received: 4 January 2008 / Accepted: 3 June 2008 / Published online: 11 July 2008

(C) Springer Science + Business Media B.V. 2008

\begin{abstract}
Nutrient and water management is crucially important in shallow-rooted vegetable production systems characterized by high input and high environmental risk. A 2-year field experiment on greenhouse cucumber double-cropping systems examined the effects of root zone nitrogen management and planting of sweet corn as a catch crop in the summer fallow period on cucumber yield and soil $\mathrm{N}_{\text {min }}$ dynamics compared to conventional practices. Cucumber fruit yields were not significantly affected by root zone $\mathrm{N}$ management and catch crop planting despite a decrease in $\mathrm{N}$ fertilizer application of 53\% compared to
\end{abstract}

Responsible Editor: Ellis Hoffland.

R. Guo $\cdot$ X. Li $\cdot$ P. Christie $\cdot$ Q. Chen $(\varangle) \cdot$ R. Jiang

F. Zhang

College of Resources and Environmental Sciences,

China Agricultural University,

2 Yuanmingyuan Xilu,

Beijing 100193, China

e-mail: qchen@cau.edu.cn

R. Guo

Ministry of Education Key Laboratory of Arid and Grassland Ecology, School of Life Sciences, Lanzhou University,

No. 222 Tianshui South Road,

Lanzhou 730000, China

P. Christie

Agricultural and Environmental Science Department, Queen's University Belfast,

Newforge Lane,

Belfast BT9 5PX, UK conventional $\mathrm{N}$ management. Soil $\mathrm{N}_{\min }$ content to a depth of $0.9 \mathrm{~m}$ decreased markedly and root zone $(0$ $0.3 \mathrm{~m})$ soil $\mathrm{N}_{\min }$ content was maintained at about $200 \mathrm{~kg} \mathrm{~N} \mathrm{ha}{ }^{-1}$. Root zone $\mathrm{N}$ management efficiently and directly reduced apparent $\mathrm{N}$ losses by $44 \%$ and $45 \%$ in 2005 and 2006, respectively. Sweet corn, the summer catch crop, depleted $\mathrm{N}_{\text {min }}$ residue in the soil profile of $1.8 \mathrm{~m}$ at harvest of winter-spring season cucumber by $304-333 \mathrm{~kg} \mathrm{~N}^{-1}$, which contributed 19$22 \%$ reduction in $\mathrm{N}$ loss. Compared to conventional $\mathrm{N}$ management, $\mathrm{N}$ loss was reduced by $56 \%$ under root zone $\mathrm{N}$ management and catch crop planting.

Keywords Sweet corn · Catch crop · Greenhouse cucumber $\cdot \mathrm{N}_{\min } \cdot$ Root zone $\mathrm{N}$ management

\section{Introduction}

Recent investigations have revealed that excessive $\mathrm{N}$ fertilizer applications with fertilizer $\mathrm{N}$ recovery rates of less than $10 \%$ are commonly practiced in intensive greenhouse vegetable production systems in northern China (Chen et al. 2004; Zhang et al. 1996; Zhu et al. 2005). Consequently, very high proportions of unused nutrients accumulate in the soil, and $\mathrm{N}$ is released into the environment through nitrate leaching, denitrification and $\mathrm{NH}_{3}$ volatilization (Cabrera and Chiang 1994; Fox et al. 1996; Gollany et al. 2004; He et al. 2007; Ramos et al. 2002). Double cropping systems with two vegetable crops per year are widespread in northern 
China using unheated greenhouses constructed with a clay or brick wall with bamboo supports attached that are covered with polyethylene film. High soil fertility, long term continuous cropping and low soil temperatures from late autumn to early spring are important factors that may inhibit root development in greenhouse vegetables. This may lead to low nutrient use efficiency with consequent negative environmental impacts.

Due to the requirements of high yield and good quality it is necessary to maintain adequate $\mathrm{N}$ concentrations and water supply in the root zone in greenhouse vegetable (including cucumber) growth (Mayfield et al. 2002). However, rapid growth rates and poor root systems in greenhouse vegetables result in relatively high critical levels of water and nutrient supply. Frequent and excessive $\mathrm{N}$ side-dressing and irrigation are major features of conventional management systems, and are employed to maintain adequate $\mathrm{N}$ concentrations in the root zone. The result is poor control of root zone $\mathrm{N}$ supply and ready leaching of nitrate out of the root zone because of the shallow rooting systems of some vegetable species (Thorup-Kristensen 2006; Verma et al. 2007).

Achieving the optimum $\mathrm{N}$ addition to maximize yield while minimizing environmental impact is an important goal of best management practices. Root zone $\mathrm{N}$ management based on the soil $\mathrm{N}_{\text {min }}$ test before $\mathrm{N}$ side-dressing and the $\mathrm{N}$ uptake pattern of the plants may be the key to improving $\mathrm{N}$ use efficiency. This involves (1) maintaining a critical $\mathrm{N}$ concentration in the root zone by determining the $\mathrm{N}$ supply from the soil and from organic and inorganic fertilizers, (2) synchronizing nutrient supply with critical crop nutrient demand at different growth stages, and (3) spatially optimizing nutrient and water supply in the root environment. Using these strategies $73 \%$ of $\mathrm{N}$ fertilizer was saved in a continuous three-season greenhouse tomato cropping system (He et al. 2007). However, significant losses of nitrate- $\mathrm{N}$ in drainage discharge still continued to occur because of long-term surplus nutrient supply and very high soil fertility through excessive application of organic manures and nitrogen fertilizers, together with excessive irrigation (He et al. 2007; Strock et al. 2004) and heavy rainfall events in the summer season when the polyethylene covered greenhouses are opened on the North China Plain (Chen et al. 2005; He et al. 2003).

High soil $\mathrm{N}$ mineralization rates may contribute to the leachable $\mathrm{N}$ outside the crop growing period
(Addiscott et al. 1991; Powlson 1993). It is possible to recover residual soil mineral $\mathrm{N}$ by prolonging the vegetable growing season or planting a catch crop during the fallow period (Thorup-Kristensen et al. 2003). A number of crops with deep root systems and high $\mathrm{N}$ uptake have been selected as winter cover crops to scavenge residual $\mathrm{NO}_{3}{ }^{-}$during the winter in Europe and the United States (Kuo and Jellum 2002; Logsdon et al. 2002; Meisinger et al. 1991; Thomsen and Christensen 1999; Thomsen 2005; Weinert et al. 2002). It seems that non-leguminous cover crops may potentially lower $\mathrm{NO}_{3}{ }^{-}$leaching by $29-94 \%$ in comparison to legumes for which the corresponding range was 6-48\% (Sainju and Singh 1997). Kuo et al. (1995) found that rye and annual ryegrass (Lolium multiflorum Lam.) with extensive root systems significantly lowered $\mathrm{NO}_{3}{ }^{-}$concentrations in soil leachates in comparison with fallow soil, whereas hairy vetch actually increased the leachate $\mathrm{NO}_{3}{ }^{-}$concentrations.

Cucumber, one of the most important vegetables in China, is commonly planted in open fields and greenhouses. Two-season cucumber is continuously planted from February to June in the winter-spring season (WS season) and from September to the following January in the autumn-winter season (AW season) in greenhouses in northern China. Features of cucumber root systems include widely spreading surface laterals and a vertically penetrating taproot. The horizontally spreading roots in the surface soil were found to make substantial growth in transplanted cucumber (Weaver and Bruner 1927). Because of the very rapid and extensive growth of the roots (largely in the surface layers of the soil) the top $0.3 \mathrm{~m}$ of the soil profile is regarded as the rootzone layer. Furthermore, shallow and poor root development due to continuous cropping contributes to an increasing risk of nitrate leaching.

It would be preferable to select a plant species with rapid biomass accumulation and high $\mathrm{N}$ uptake capacity (especially $\mathrm{C}_{4}$ plant species) as summer catch crops in order to deplete residual $\mathrm{N}$ in the soil profile (Snapp et al. 2005; Wang et al. 2005). In the present study sweet corn was selected as a possible catch crop in the cucumber double cropping system and our objectives were (1) to investigate the combined cucumber yield responses to reduced $\mathrm{N}$ inputs and inclusion of the catch crop in the rotation and (2) to monitor the effects of root zone $\mathrm{N}$ management and catch crop planting on soil $\mathrm{N}_{\text {min }}$ dynamics during the year-round cropping system. 


\section{Materials and methods}

Experimental site

A typical 5-year-old commercial greenhouse was randomly selected for the field experiment in Changping county, Beijing suburbs from 2005 to 2007. The greenhouse was covered with polyethylene film (ground area $6 \times 72 \mathrm{~m}$ ) without supplementary lighting or heating. Field experiments were conducted on a silty loam soil. The surface soil in the greenhouse $(0-0.3 \mathrm{~m}$ layer) had a $\mathrm{pH}$ (in water) of 6.1, an electrical conductivity (EC) value with the extracting ratio of 1:5 (soil/water) of $214 \mu \mathrm{s} \mathrm{cm}{ }^{-1}$, an initial soil $\mathrm{N}_{\text {min }}$ of $255 \mathrm{~kg} \mathrm{~N} \mathrm{ha}{ }^{-1}$ and an organic matter content of $24.0 \mathrm{~g} \mathrm{~kg}^{-1}$ prior to the experiments. Total N, Olsen-P and $\mathrm{NH}_{4} \mathrm{OAc}-\mathrm{K}$ were $1.78 \mathrm{~g} \mathrm{~kg}^{-1}, 305 \mathrm{mg} \mathrm{kg}^{-1}$ and $470 \mathrm{mg} \mathrm{kg}^{-1}$, respectively. Soil texture and soil bulk density in the top $1.8 \mathrm{~m}$ of the soil profile are shown in Table 1. Groundwater with a nitrate concentration of $0.44 \mathrm{mg} \mathrm{L}^{-1}$ was used for irrigation.

Daily soil temperature, air temperature and precipitation were recorded during the summer seasons of 2005 and 2006 (Fig. 1). Total amounts of precipitation were 299 and $491 \mathrm{~mm}$ in 2005 and 2006, respectively (Fig. 1). From 21 July to the harvest of sweet corn in both years, the precipitation rates were 270 and $244 \mathrm{~mm}$ in 2005 and 2006, respectively, and the greenhouse was uncovered during this period. Precipitation data were collected from a nearby weather station. Air temperatures were recorded daily at 10:00 during the experiment (Fig. 1).

Crop establishment and management

Cucumber seedlings (Cucumis sativus L. cv. Jinglu no. 3 in 2005 and cv. Zhongte no. 25 in 2006) with two leaves were transplanted by hand, with double rows of 0.9-m row spacing and $0.3-\mathrm{m}$ seedling spacing on the seedbed (Fig. 2) on 11 March 2005 and 15 February 2006 (WS season), and 8 September 2005 and 10 September 2006 (AW season). Fruit harvesting started on 21 April and 18 October in 2005 and 9 April and 9 October in 2006 (Fig. 3). Once the final harvest was completed, cucumber vines were immediately removed from the greenhouse to minimize infection with root fungal diseases. Sweet corn seedlings with three leaves were transplanted with $0.6-\mathrm{m}$ row spacing and $0.3-\mathrm{m}$ plant spacing in the treatments with summer catch crop planting at the end of June and the sweet corn was harvested in September.

Experimental treatments

The treatments were designed as follows:

(1) N00: Neither organic manure nor chemical fertilizer $\mathrm{N}$ was applied.

(2) Nm0: Only organic manure was broadcast as a basal fertilizer and no chemical $\mathrm{N}$ fertilizer was applied. 75, 22.5, 11 and $18 \mathrm{t} \mathrm{ha}^{-1}$ of chicken manure (with total $\mathrm{N}$ inputs of 671, 200, 146 and $205 \mathrm{~kg} \mathrm{~N} \mathrm{ha}^{-1}$ ) were broadcast before transplanting in the four growing seasons. Organic matter, total $\mathrm{P}$ and total $\mathrm{K}$ contents of the organic manures used in 2006 were $30.9 \%, 12.6 \mathrm{~g} \mathrm{~kg}^{-1}$ $\left(\mathrm{P}_{2} \mathrm{O}_{5}\right)$ and $2.45 \mathrm{~g} \mathrm{~kg}^{-1}\left(\mathrm{~K}_{2} \mathrm{O}\right)$.

(3) Nmt: With the same application of chicken manure as the $\mathrm{Nm} 0$ treatment, $\mathrm{N}$ fertilizer was side-dressed in the cucumber growing period based on conventional practice in the region. The total $\mathrm{N}$ rates applied by topdressing were $710,675,666$, and $590 \mathrm{~kg} \mathrm{~N} \mathrm{ha}^{-1}$ in the WS and AW seasons of 2005 and WS and AW seasons of 2006, respectively.

(4) Nmr: with the same application rate of chicken manure as $\mathrm{Nm} 0$ treatment, $\mathrm{N}$ side-dressing was
Table 1 Soil texture and bulk density at different soil depths in the experimental field at Changping

${ }^{\text {a }}$ n.d. Not detected

\begin{tabular}{lllcc}
\hline Soil depth $(\mathrm{m})$ & \multirow{2}{*}{ Soil bulk density $\left(\mathrm{kg} \mathrm{m}^{-3}\right)$} & \multicolumn{3}{l}{ Soil particle distribution at different depths $(\mu \mathrm{m})$} \\
\cline { 3 - 5 } & & $20-2,000$ & $2-20$ & $\leq 2$ \\
\hline $0-0.3$ & 1,420 & 38.6 & 60.6 & 0.9 \\
$0.3-0.6$ & 1,620 & 39.0 & 59.4 & 1.7 \\
$0.6-0.9$ & 1,510 & 27.8 & 69.1 & 3.1 \\
$0.9-1.2$ & 1,510 & 12.1 & 84.8 & 3.2 \\
$1.2-1.5$ & 1,550 & 9.1 & 86.6 & 4.3 \\
$1.5-1.8$ & n.d. $^{\text {a }}$ & 21.1 & 76.0 & 3.0 \\
\hline
\end{tabular}


Fig. 1 Daily precipitation and air temperature during the growing seasons in greenhouse cucumber cropping systems in the Beijing suburbs
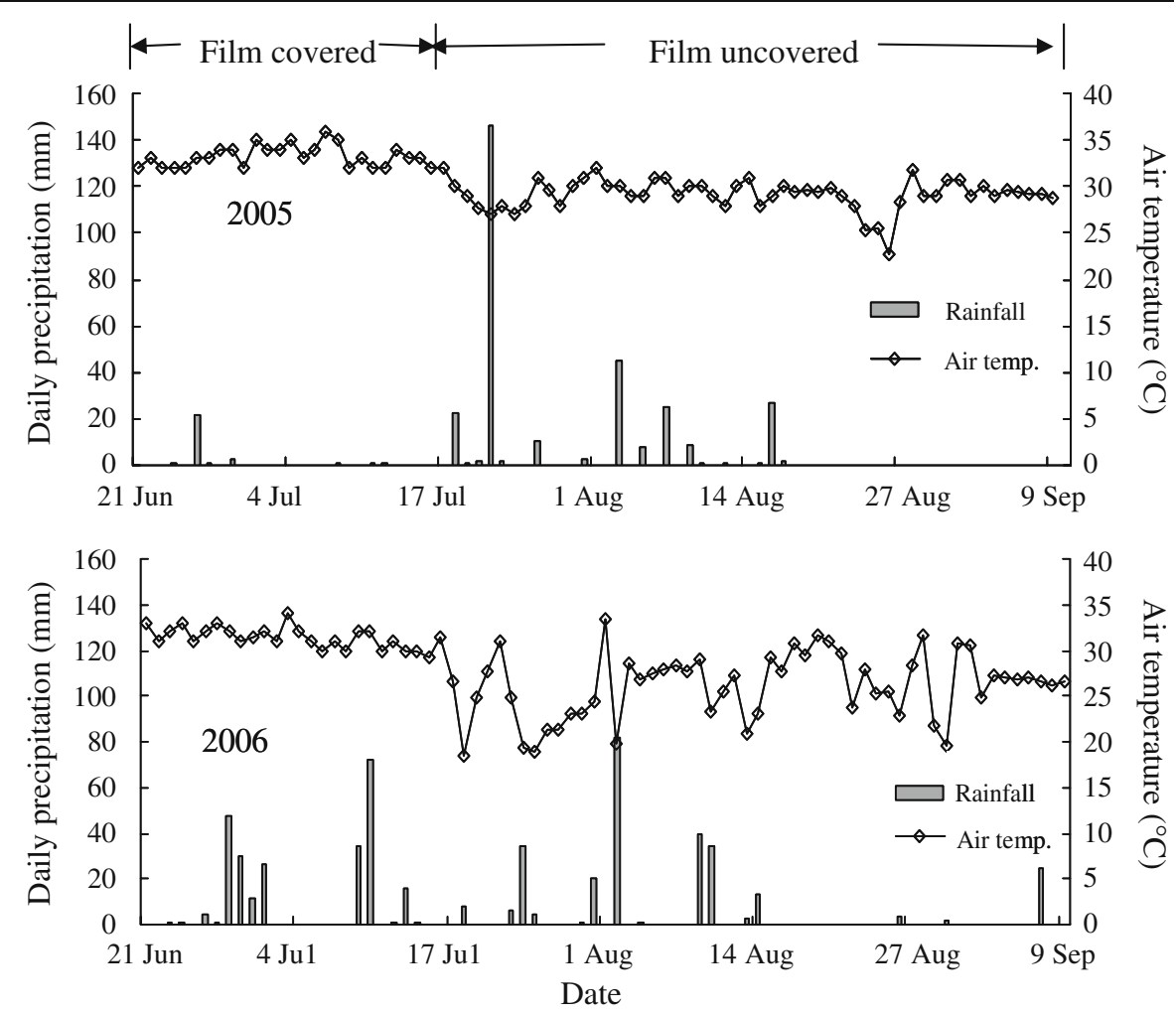

based on the $\mathrm{N}$ target value (including soil $\mathrm{N}_{\text {min }}$ buffer and crop uptake) and soil $\mathrm{N}_{\min }$ in the root zone. The equation was as follows:

Recommended fertilizer $\mathrm{N}$

$=\left[\right.$ Output (crop $\mathrm{N}$ uptake + soil $\mathrm{N}_{\min }$ buffer $\left.)\right]$

- [Input (soil $\mathrm{N}_{\min }$ in the root zone before side

- dressing)]
Here, soil $\mathrm{N}_{\min }$ buffer refers to the critical soil residual $\mathrm{N}_{\min }$ in the root zone required to maintain crop growth, which was modified to $200 \mathrm{~kg} \mathrm{~N} \mathrm{ha}^{-1}$, referenced from substrate cucumber experiments (Kotsiras et al. 2002). Seasonal N uptake by cucumber shoots was calculated based on the following formula describing cucumber yield formation in the same county (Pei 2002).
Fig. 2 Field layout of cucumber (A) and sweet corn (B) planting and the locations of soil and root sampling of cucumber and sweet corn

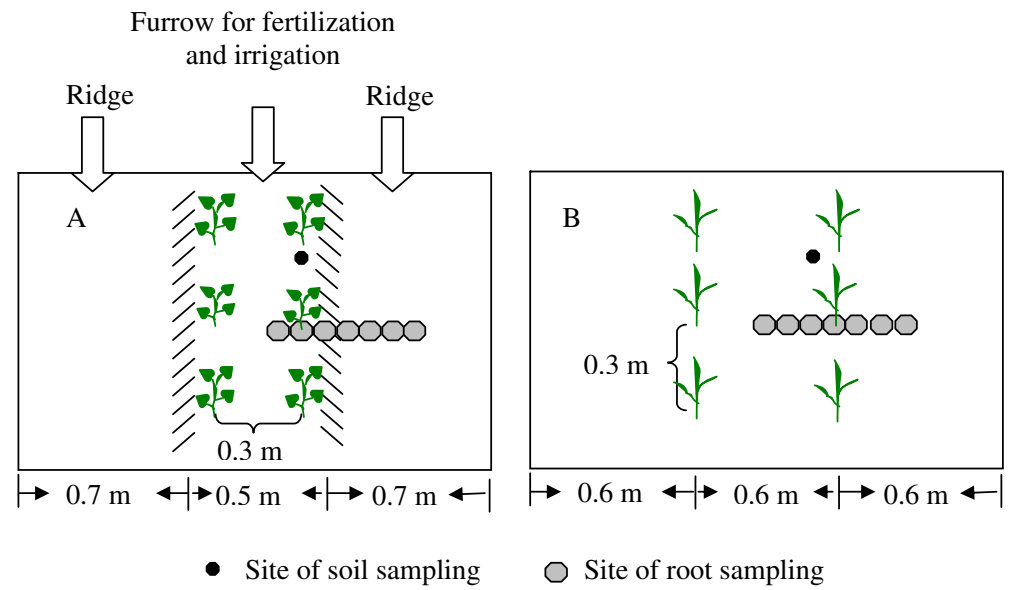


Fig. 3 Planting periods of different seasonal greenhouse cucumber and the summer catch crop (sweet corn) during the period 2005-2006. WS Winterspring season, AS autumnwinter season

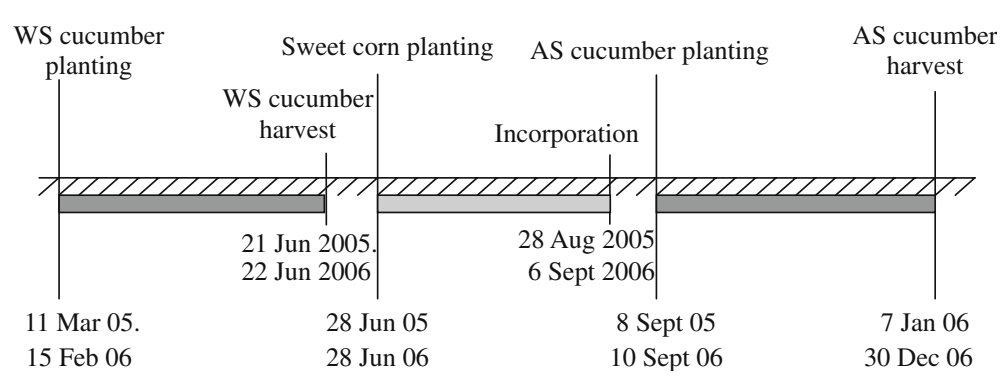

WS season:

$$
\begin{aligned}
\text { Nuptake }= & -0.0337 \mathrm{DAT}^{2}+8.2533 \mathrm{DAT} \\
& -216.04
\end{aligned}
$$

AW season:

$$
\begin{aligned}
\text { Nuptake }= & -0.0174 \mathrm{DAT}^{2}+4.1953 \mathrm{DAT} \\
& -79.94
\end{aligned}
$$

where DAT denotes days after transplanting.

The total side-dressing $\mathrm{N}$ rates in $\mathrm{Nmr}$ were 152,405 , 319 and $310 \mathrm{~kg} \mathrm{~N} \mathrm{ha}^{-1}$ in the WS and AW seasons of 2005 and the WS and AW seasons of 2006, respectively.

(5) $\mathrm{Nmr}+\mathrm{C}$ : On the basis of the Nmr treatment, sweet corn was planted as a catch crop during the summer fallow period and no straw of sweet corn was incorporated into the soil after harvest.

(6) $\mathrm{Nmr}+\mathrm{CS}$ : On the basis of the $\mathrm{Nmr}+\mathrm{C}$ treatment, the straw of sweet corn was incorporated into the soil after harvest.

The experiment was a completely randomized block design with three replicates and the size of each replicate plot was $4.8 \times 5.5 \mathrm{~m}$. Furrow irrigation systems were adopted in the greenhouse based on the conventional schedule. Urea was dissolved and flushed into the soil with furrow irrigating water for $\mathrm{N}$ side-dressing. The total irrigation rates were 367 , 330, 266 and $198 \mathrm{~mm}$ in the WS and AW seasons of 2005 and the WS and AW seasons of 2006, respectively (Fig. 4). No irrigation or fertilizer was applied during the sweet corn planting season except for $35 \mathrm{~mm}$ of irrigation at transplanting.

Field management followed conventional practices. Weeds were removed by hand. Fungicide sprays were used to control powdery mildew and downy mildew which frequently occur during cucumber growth.
Nitrogen balance calculation

$\mathrm{N}$ balance was calculated following Eq. 2 as described by Patil et al. (2001).

$$
\begin{aligned}
\mathrm{N}_{\text {balance }}= & \mathrm{N}_{\text {min initial }}+\mathrm{N}_{\text {manure }}+\mathrm{N}_{\text {fer }}-\mathrm{N}_{\text {crop }} \\
& -\mathrm{N}_{\text {min harvest }}
\end{aligned}
$$

Where:

\begin{tabular}{ll}
\hline $\mathrm{N}_{\text {balance }}$ & $\mathrm{N}$ balance \\
$\mathrm{N}_{\text {min initial }}$ & soil $\mathrm{N}_{\text {min }}$ to $0.3 \mathrm{~m}$ depth before transplanting \\
$\mathrm{N}_{\text {manure }}$ & $\mathrm{N}$ from chicken manure \\
$\mathrm{N}_{\text {fer }}$ & $\mathrm{N}$ from applied chemical fertilizer \\
$\mathrm{N}_{\text {crop }}$ & total $\mathrm{N}$ uptake in cucumber aboveground parts \\
$\mathrm{N}_{\text {min harvest }}$ & soil $\mathrm{N}_{\text {min }}$ to $0.3 \mathrm{~m}$ depth at harvest \\
\hline
\end{tabular}

Sampling and analysis

Soil samples were taken from the top $0.9 \mathrm{~m}$ in each plot at $0.3 \mathrm{~m}$ intervals two or three days before $\mathrm{N}$ side-dressing during the cucumber growing season. In the sweet corn growing and fallow periods soil sampling was conducted from the $0-0.3,0.3-0.6$ and $0.6-0.9 \mathrm{~m}$ soil layers every $2-3$ weeks. Before planting and after harvesting of cucumber and sweet corn, soil samples were taken to $1.8 \mathrm{~m}$ depth at $0.3-\mathrm{m}$ intervals. Six soil cores were mixed thoroughly and passed through a 4-mm sieve. Sub-samples of $12 \mathrm{~g}$ soil were extracted at a ratio of 1:10 (dry soil weight/ extractant volume) with $0.01 \mathrm{~mol} / \mathrm{L} \mathrm{CaCl}$, shaken for $1 \mathrm{~h}$ and filtered. The filtrates were analyzed for mineral $\mathrm{N}$ with a TRAACS Model 2000 continuous flow autoanalyzer (Houba et al. 1986). Water contents in the soil samples were determined gravimetrically to calculate soil $\mathrm{N}_{\min }$ on a dry soil basis.

Cucumber samples were taken at intervals of 23 weeks to measure dry matter weight and $\mathrm{N}$ content. 


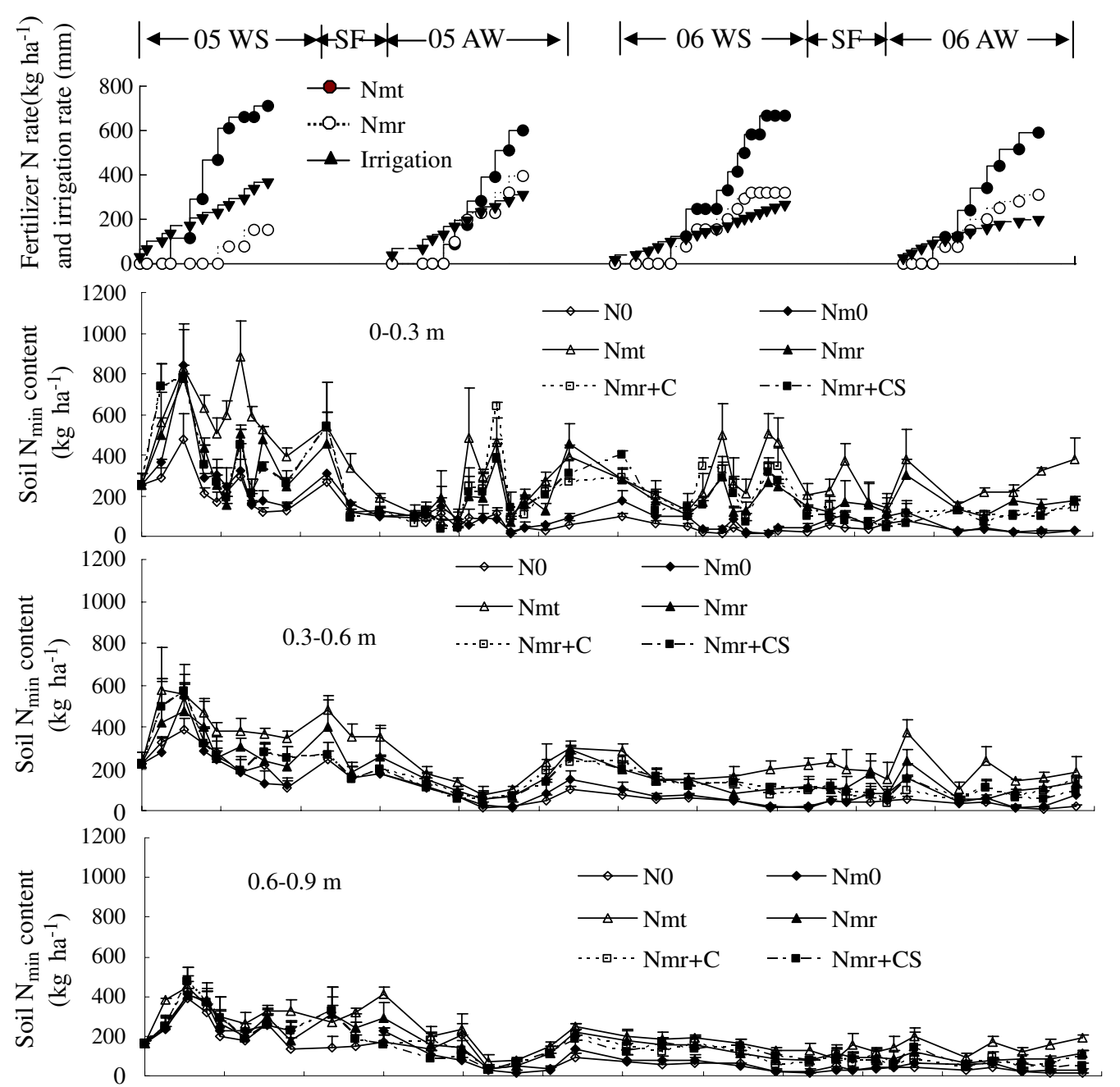

11-Mar 6-May 1-Jul 26-Aug 21-Oct 16-Dec 10-Feb 7-Apr 2-Jun 28-Jul 22-Sep 17-Nov 12-Jan

Fig. $4 \mathrm{~N}$ side-dressing/irrigation rates and soil $\mathrm{N}_{\min }$ contents in the soil profile to a depth of $0.9 \mathrm{~m}$ under different treatments from 2005 to 2006. WS Winter-spring season, AS autumnwinter season, SF summer fallow season. N00, Nm0, Nmt, Nmr, $\mathrm{Nmr}+\mathrm{C}$ and $\mathrm{Nmr}+\mathrm{CS}$ denote control, $\mathrm{N}$ from organic manure,

Commercial fruits $(2.5-3.0 \mathrm{~cm}$ in diameter and $25-$ $30 \mathrm{~cm}$ long) were picked following conventional harvest practice and weighed from 24 plants in each plot. Sweet corn was sampled when soil sampling was conducted. Fresh shoot samples were collected and dried at $70^{\circ} \mathrm{C}$ to constant weight. The dried shoots were ground before determination of total $\mathrm{N}$ content. A modified Kjeldahl method with addition of salicylic acid was used to analyze total $\mathrm{N}$ in the plant samples.

Cucumber and sweet corn roots were sampled at harvest. Root samples were taken with an Eijelkamp root auger (length $0.15 \mathrm{~m}$, diameter $0.08 \mathrm{~m}$ ) to a depth of conventional $\mathrm{N}$ management and root zone $\mathrm{N}$ management, root zone $\mathrm{N}$ management with sweet corn as catch crop and root zone $\mathrm{N}$ management with sweet corn as catch crop and with residue incorporation after the sweet corn harvest. Bars represent SD of means with three replicates per treatment

$0.6 \mathrm{~m}$ in the case of cucumber and $1.05 \mathrm{~m}$ for sweet corn in $0.15-\mathrm{m}$ increments (Fig. 2). Soil cores with root samples were stored for a maximum of 6 days in polyethylene bags under refrigeration $\left(4^{\circ} \mathrm{C}\right)$ before washing. Roots were collected after the soil was passed through a 0.5-mm sieve with flowing tap water. Debris, weeds, and dead roots were sorted by hand from the fresh roots during washing, based on visual observation of fresh roots appearing light in color. Samples were frozen prior to length determination. Root length was estimated using a line intersect method (Tennant 1975) with $1.0 \times$ $1.0 \mathrm{~cm}$ square grids. 
Data analysis

The data were subjected to analysis of variance and pairs of mean values were compared by least significant difference (LSD) at the 5\% level using version 6.12 of the SAS software package (SAS Institute Inc., Cary, NC, USA).

\section{Results}

Cucumber yields and sweet corn biomass

Figure 5 summarized the variation in marketable yield of cucumber with different $\mathrm{N}$ fertilizer and catch crop treatments. The fruit yield of cucumber in the AW season was significantly lower than that in the WS season due to low temperatures during the fruiting stage in the AW season. No significant difference was found in cucumber yield between $\mathrm{Nmr}$ and Nmt treatments in the four growing seasons despite the $53 \%$ reduction in fertilizer $\mathrm{N}$ application in the $\mathrm{Nmr}$ treatment. Root zone $\mathrm{N}$ management, sweet corn cropping and straw incorporation played no significant part in fruit yield loss in the first and second succeeding cucumber growing seasons or with the sum of the four cucumber seasons, indicating that sweet corn may be intro- duced as a summer catch crop in greenhouse cucumber cropping systems.

Adequate rainfall in the summer season created optimum growth conditions for sweet corn. At harvest the dry biomass reached 9,876 and $8,786 \mathrm{~kg} \mathrm{ha}^{-1}$ in 2005 and 2006, respectively. Fresh yields of sweet corn averaged 7,671 and 7,115 $\mathrm{kg} \mathrm{ha}^{-1}$ in 2005 and 2006.

Root distribution of cucumber and sweet corn

Seasonal differences in root growth were found in the later growth stages of cucumber between the WS and AW seasons (Table 2). Lower temperatures could be an important explanation for the lower root length densities in the later growth stages of cucumber in the AW season compared with the WS season. Nearly $90 \%$ of cucumber root length was distributed in the top $0.3 \mathrm{~m}$ of the soil profile in the later growth stage of cucumber in both growing seasons.

The rapid root development stage of sweet corn occurred before the polyethylene film was removed (21 July) during the summer season (Table 3). $89 \%$ of total root length measured to a soil depth of $75 \mathrm{~cm}$ was distributed within the top $0.3 \mathrm{~m}$ of the soil profile in both years. At harvest, sweet corn roots had penetrated to a depth of $1.05 \mathrm{~m}$ and the root length below $0.3 \mathrm{~m}$ depth accounted for $24-29 \%$ of total root length in the top $1.05 \mathrm{~m}$ of the soil profile.

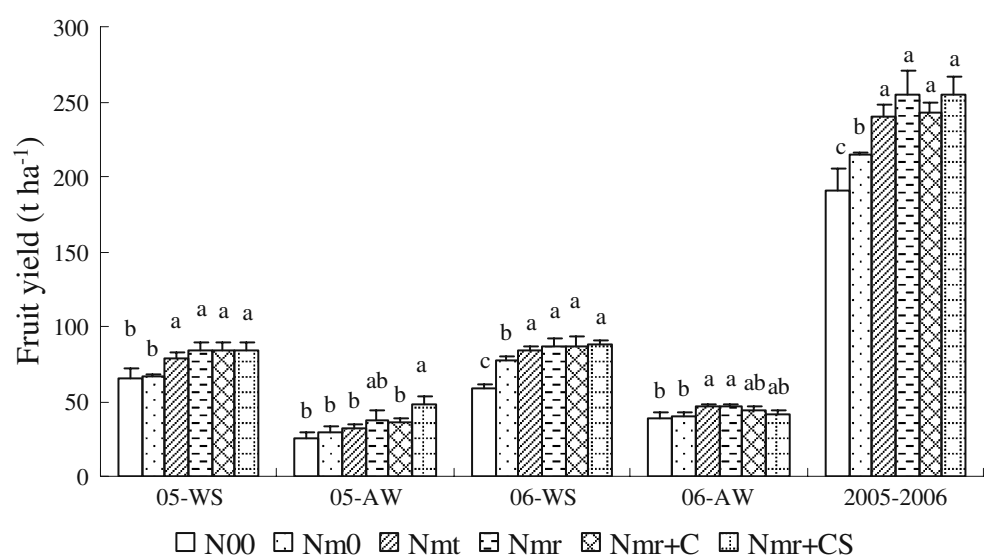

Fig. 5 Fruit yield of cucumber under different $\mathrm{N}$ management and sweet corn treatments. WS Winter-spring season, AS autumn-winter season. $\mathrm{N} 00, \mathrm{Nm} 0, \mathrm{Nmt}, \mathrm{Nmr}, \mathrm{Nmr}+\mathrm{C}$ and $\mathrm{Nmr}+\mathrm{CS}$ denote control, $\mathrm{N}$ from organic manure, conventional $\mathrm{N}$ management and root zone $\mathrm{N}$ management, root zone $\mathrm{N}$ management with sweet corn as catch crop and root zone $\mathrm{N}$ management with sweet corn as catch crop and with residue incorporation after the sweet corn harvest. Bars represent SD of means with three replicates per treatment. The same letter in the same season denotes no significant difference by LSD at the $5 \%$ level 
Table 2 Mean root length density $\left(\mathrm{cm} \mathrm{cm}^{-3}\right)$ of greenhouse cucumber in the Nmr treatment in the autumn-winter season of 2005 and winter-spring season of 2006

\begin{tabular}{|c|c|c|c|c|c|c|}
\hline \multirow[t]{2}{*}{ Soil depth (m) } & \multicolumn{3}{|c|}{2005 autumn-winter season } & \multicolumn{3}{|c|}{2006 winter-spring season } \\
\hline & 18 Oct & $18 \mathrm{Nov}$ & $30 \mathrm{Dec}$ & $5 \mathrm{Apr}$ & 3 May & 21 Jun \\
\hline $0-0.15$ & 0.79 & 1.62 & 0.66 & 0.79 & 1.52 & 1.46 \\
\hline $0.15-0.30$ & 0.32 & 0.81 & 0.37 & 0.32 & 0.75 & 0.51 \\
\hline $0.30-0.45$ & n.d. & 0.34 & 0.12 & n.d. & 0.37 & 0.24 \\
\hline $0.45-0.60$ & n.d. & 0.07 & n.d. & n.d. & 0.09 & n.d. \\
\hline
\end{tabular}

${ }^{a}$ n.d. Not detected

Soil $\mathrm{N}_{\text {min }}$ dynamics under fertilizer $\mathrm{N}$ management

Soil $\mathrm{N}_{\min }$ content at $0-0.9 \mathrm{~m}$ depth was greatly reduced by root zone $\mathrm{N}$ management during the experiment in contrast to conventional $\mathrm{N}$ management (Fig. 4). Furthermore, soil $\mathrm{N}_{\min }$ content with root zone $\mathrm{N}$ management was maintained near to the $\mathrm{N}_{\text {min }}$ buffer used in the determination of $\mathrm{N}$ recommendations.

Residual $\mathrm{N}_{\min }$ in the soil profile was greatly influenced by different $\mathrm{N}$ management practices during the experiment (Fig. 6). More $\mathrm{N}$ was retained in the $0.3-1.8 \mathrm{~m}$ soil layer by frequent $\mathrm{N}$ side-dressing in both 2005 and 2006 (Table 4). After the cucumber harvest in the WS season of 2005 , residual soil $\mathrm{N}_{\min }$ below the cucumber root zone increased by $176 \mathrm{~kg} \mathrm{~N}$ $\mathrm{ha}^{-1}$ in the N00 treatment, $354 \mathrm{~kg} \mathrm{~N}^{-1}$ in Nm0, $818 \mathrm{~kg} \mathrm{~N} \mathrm{ha}^{-1}$ in $\mathrm{Nmt}$ and $418 \mathrm{~kg} \mathrm{~N} \mathrm{ha}^{-1}$ in $\mathrm{Nmr}$ contrast to that before transplanting (10 March 2005). During the subsequent fallow period there was an evident increase in $\mathrm{N}_{\min }$ content in the $0.3-1.8 \mathrm{~cm}$ zone of the soil profile of 193 (N00), 293 (Nm0), 538
(Nmr) and $768 \mathrm{~kg} \mathrm{~N} \mathrm{ha}^{-1}$ (Nmt) compared to the cucumber harvest in WS season in 2005.

However, by the harvest of the 2006 WS season soil $\mathrm{N}_{\text {min }}$ content in the $0.3-1.8 \mathrm{~m}$ soil layer was significantly lowered by 895 (N00), 1,068 (Nm0), 1,536 (Nmt) and $1,217 \mathrm{~kg} \mathrm{~N} \mathrm{ha}^{-1}(\mathrm{Nmr})$ compared to the end of the fallow period in 2005. A rapid decrease in soil $\mathrm{N}_{\text {min }}$ content in the $0.3-1.8 \mathrm{~m}$ soil layer was found from the end of the fallow period in 2005 (26 Aug $2005)$ to the end of the cucumber harvest in the WS season of 2006 (21 Jun 2006). During the 2006 fallow period, there was a smaller increase in soil $\mathrm{N}_{\text {min }}$ with $\mathrm{Nm} 0, \mathrm{Nmt}$ and Nmr treatments in comparison with the 2005 fallow period. At the cucumber harvest in the 2006 AW season the soil $\mathrm{N}_{\min }$ content in the $0.3-1.8 \mathrm{~m}$ soil layer decreased by 65 (N00), $180(\mathrm{Nm} 0), 162$ (Nmt) and $115(\mathrm{Nmr}) \mathrm{kg} \mathrm{N} \mathrm{ha}^{-1}$ in contrast to the end of the 2006 fallow period, indicating that the amount of organic manure applied was important for soil $\mathrm{N}$ accumulation below the root zone. In $2005,671 \mathrm{~kg} \mathrm{~N} \mathrm{ha}^{-1}$ in organic manure was applied as a basal fertilizer,

Table 3 Mean root length density and percentage of total root length at different soil depth categories in sweet corn under the Nmr $+\mathrm{C}$ treatment in 2005 and 2006

\begin{tabular}{|c|c|c|c|c|c|c|c|c|}
\hline \multirow[t]{3}{*}{ Soil depth (m) } & \multicolumn{4}{|c|}{ Root length density $\left(\mathrm{cm} \mathrm{cm}^{-3}\right)$} & \multicolumn{4}{|c|}{$\begin{array}{l}\text { Percentage of total root length at different soil } \\
\text { depth categories }(\%)\end{array}$} \\
\hline & \multicolumn{2}{|l|}{$21 \mathrm{Jul}$} & \multicolumn{2}{|c|}{ At harvest } & \multicolumn{2}{|c|}{$21 \mathrm{Jul}$} & \multicolumn{2}{|c|}{ At harvest } \\
\hline & 2005 & 2006 & 2005 & 2006 & 2005 & 2006 & 2005 & 2006 \\
\hline $0-0.15$ & 1.08 & 1.54 & 1.17 & 1.06 & 66 & 67 & 46 & 51 \\
\hline $0.15-0.30$ & 0.38 & 0.51 & 0.65 & 0.49 & 23 & 22 & 25 & 24 \\
\hline $0.30-0.45$ & 0.10 & 0.12 & 0.36 & 0.28 & 6 & 5 & 14 & 13 \\
\hline $0.45-0.60$ & 0.05 & 0.09 & 0.19 & 0.14 & 3 & 4 & 7 & 7 \\
\hline $0.60-0.75$ & 0.04 & 0.07 & 0.07 & 0.03 & 2 & 3 & 3 & 1 \\
\hline $0.75-0.90$ & n.d. ${ }^{\mathrm{a}}$ & n.d. & 0.07 & 0.04 & & & 3 & 2 \\
\hline $0.90-1.05$ & n.d. & n.d. & 0.06 & 0.02 & & & 2 & 1 \\
\hline
\end{tabular}

${ }^{\mathrm{a}}$ n.d. Not detected 
Fig. $6 \mathrm{~N}_{\text {min }}$ content in the top $1.8 \mathrm{~m}$ of the soil profile of at the end of harvest over four cropping seasons in the greenhouse cucumber cropping system. Bars represent $\mathrm{SD}$ of means with three replicates per treatment

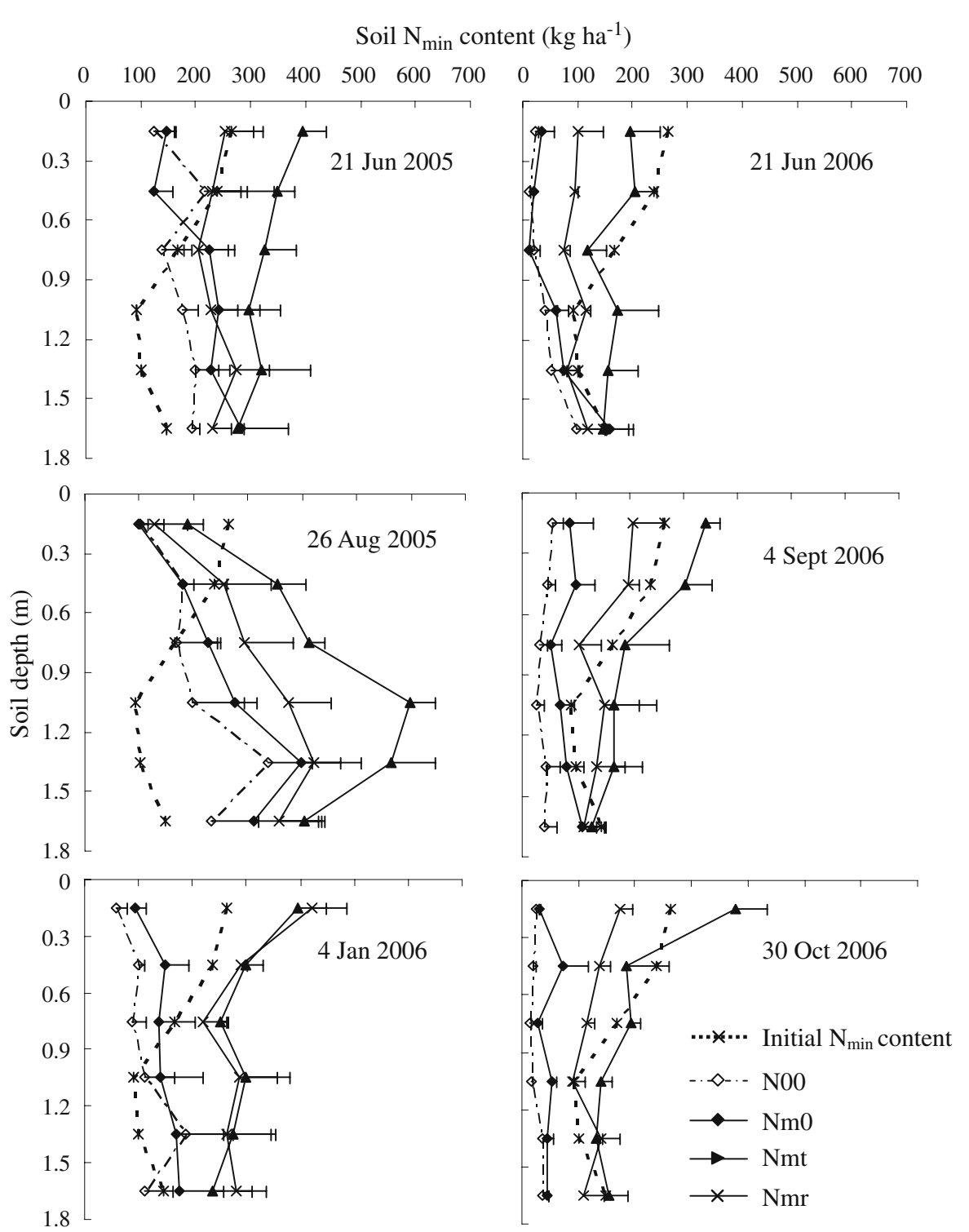

which can be regarded as traditional practice, and an evident increase in soil $\mathrm{N}_{\text {min }}$ was observed from the beginning of the 2005 WS season to the end of the 2005 fallow period. Thereafter, $\mathrm{N}$ from organic manure was controlled at around $200 \mathrm{~kg} \mathrm{~N} \mathrm{ha}^{-1}$ for cucumber growth, and no increase in $\mathrm{N}_{\min }$ occurred in the soil profile (except in the 2006 fallow period) under the range of $\mathrm{N}$ application rates examined.

$\mathrm{N}$ uptake, soil $\mathrm{N}_{\min }$ and soil water dynamics under sweet corn cropping

Total $\mathrm{N}$ uptake by sweet corn at harvest was $187 \mathrm{~kg} \mathrm{~N}^{-1}$ in 2005 and $154 \mathrm{~kg} \mathrm{~N} \mathrm{ha}^{-1}$ in 2006 (Fig. 7). Shoot N uptake by sweet corn was up to 42 and $56 \mathrm{~kg} \mathrm{~N} \mathrm{ha}^{-1}$ from sweet corn transplanting to 21 July in 2005 and 2006. During the later growth stages of sweet corn (from 20 July to the end of the harvest), the amounts of $\mathrm{N}$ removed by the sweet corn shoots were 131 and $112 \mathrm{~kg} \mathrm{~N} \mathrm{ha}^{-1}$ in 2005 and 2006.

No rainfall reached the interior of the greenhouse before 21 July because the greenhouse was covered with polyethylene film and strong $\mathrm{N}_{\min }$ mineralization was found in the top $0.9 \mathrm{~m}$ of the soil profile in 2005 , but not in 2006 (Fig. 7). The initial soil N supply at the beginning of the fallow period might partly explain this result. After three continuous cucumber growing periods with root zone $\mathrm{N}$ management, soil 
Table 4 Soil $\mathrm{N}_{\text {min }}$ content $\left(\mathrm{kg} \mathrm{N} \mathrm{ha}^{-1}\right)$ in the $0.3-1.8 \mathrm{~m}$ deep soil zone at the end of the cucumber harvest the in greenhouse cropping system during 2005-2006

\begin{tabular}{llllllll}
\hline Treatment & 2005 & 2005 & 2005 & 2006 & 2006 & 2006 \\
& $W^{\mathrm{b}}$ & WS & Fallow & AW & WS & $\begin{array}{l}\text { Fallow } \\
4 \text { Sept }\end{array}$ & $\begin{array}{l}\text { AW } \\
\text { 30 Dec }\end{array}$ \\
& $10 \mathrm{Mar}$ & $21 \mathrm{Jun}$ & 26 Aug & 21 Jun & $1906 \mathrm{~d}$ \\
$\mathrm{~N} 00^{\mathrm{a}}$ & 745 & $921 \mathrm{~b}^{\mathrm{c}}$ & $1,114 \mathrm{~d}$ & $597 \mathrm{~b}$ & $219 \mathrm{c}$ & $190 \mathrm{~d}$ \\
$\mathrm{Nm} 0$ & 745 & $1,099 \mathrm{~b}$ & $1,392 \mathrm{c}$ & $774 \mathrm{~b}$ & $324 \mathrm{c}$ & $419 \mathrm{c}$ & $239 \mathrm{c}$ \\
$\mathrm{Nmt}$ & 745 & $1,564 \mathrm{a}$ & $2,332 \mathrm{a}$ & $1,361 \mathrm{a}$ & $796 \mathrm{a}$ & $965 \mathrm{a}$ & $802 \mathrm{a}$ \\
$\mathrm{Nmr}$ & 745 & $1,163 \mathrm{~b}$ & $1,701 \mathrm{~b}$ & $1,342 \mathrm{a}$ & $484 \mathrm{~b}$ & $705 \mathrm{~b}$ & $590 \mathrm{~b}$ \\
\hline
\end{tabular}

${ }^{\text {a }} \mathrm{N} 00, \mathrm{Nm} 0, \mathrm{Nmt}$ and $\mathrm{Nmr}$ denote control treatment, $\mathrm{N}$ from organic manure, conventional $\mathrm{N}$ management and $\mathrm{N}$ recommended management.

${ }^{\mathrm{b}}$ WS and AW denote winter-spring season and autumn-winter season.

${ }^{\mathrm{c}}$ The same letter in the same column denotes no significant difference by LSD $(P<0.05)$

$\mathrm{N}_{\text {min }}$ was lower at the beginning of the fallow period in 2006 than in 2005. In 2005 no significant difference was found in $\mathrm{N}_{\text {min }}$ content between sweet corn cropping and the fallow treatment in the top $0.3 \mathrm{~m}$ of the soil profile. However, sweet corn cropping evidently depleted $\mathrm{N}_{\min }$ compared to the fallow treatment in 2006. In both years soil $\mathrm{N}_{\min }$ at $0.3-0.9 \mathrm{~m}$ depth was reduced by sweet corn cropping with root growth and $\mathrm{N}$ uptake occurring in contrast to the fallow period. At the sweet corn harvest less $\mathrm{N}_{\text {min }}$ was retained in the top $1.8 \mathrm{~m}$ of the soil profile under sweet corn cropping compared with the fallow period (Fig. 8). Soil $\mathrm{N}_{\min }$ in the top $1.8 \mathrm{~m}$ of the soil profile was reduced by 333 and $304 \mathrm{~kg} \mathrm{~N}^{-1}$ with sweet corn cropping compared to the fallow treatment in 2005 and 2006 and soil water content in the $0-1.8 \mathrm{~m}$ soil layer increased with or without sweet corn cropping in contrast to the beginning of the fallow period. No significant difference in soil water content was found between $\mathrm{Nmr}$ and $\mathrm{Nmr}+\mathrm{C}$ treatments after the fallow period (Fig. 8).

Soil N supply following incorporation of sweet corn straw

After the sweet corn harvest, $\mathrm{N}$ incorporation in sweet corn straw amounted to 91 and $68 \mathrm{~kg} \mathrm{~N}^{-1}$ in 2005 and 2006, and sweet corn straw biomass reached 5,239 and 4,183 $\mathrm{kg} \mathrm{ha}^{-1}$ in 2005 and 2006. Figure 3 showed that sweet corn cropping with or without soil incorporation of the catch crop at harvest had little effect on $\mathrm{N}_{\min }$ in the top $90 \mathrm{~cm}$ of the soil profile in the 2005 AW season or the 2006 WS season. However, soil $\mathrm{N}_{\text {min }}$ in the top $0.3 \mathrm{~m}$ soil layer under $\mathrm{Nmr}+\mathrm{C}$ and $\mathrm{Nmr}+\mathrm{CS}$ treatments appeared to be low in contrast to the Nmr treatment in the 2006 AW cucumber season due to continuous sweet corn cropping during the fallow period, but there were no apparent differences among these treatments in $\mathrm{N}_{\text {min }}$ content at $0.3-0.9 \mathrm{~m}$ depth. Although no difference in soil $\mathrm{N}_{\min }$ at $0-0.9 \mathrm{~m}$ depth was observed between $\mathrm{Nmr}+\mathrm{C}$ and $\mathrm{Nmr}+\mathrm{CS}$ treatments, soil $\mathrm{N}_{\min }$ at $0-0.9 \mathrm{~m}$ depth under $\mathrm{Nmr}+\mathrm{CS}$ tended to increase at the cucumber harvest in the 2006 AW season.

\section{$\mathrm{N}$ balance}

The different $\mathrm{N}$ fertilizer treatments had pronounced effects on $\mathrm{N}$ balance (Table 5). A balanced $\mathrm{N}$ recommendation strategy in the $\mathrm{Nmr}$ treatment has allowed substantial reductions in $\mathrm{N}$ losses of $44 \%$ and $45 \%$ compared to traditional $\mathrm{N}$ management $(\mathrm{Nmt})$ in 2005 and 2006. Compared to the Nmr treatment, $\mathrm{N}$ losses were reduced by $22 \%$ and $19 \%$ with sweet corn cropping in 2005 and 2006. The incorporation of sweet corn residues at harvest may have lowered $\mathrm{N}$ losses by $22 \%$ in 2005 but had little effect on $\mathrm{N}$ losses in 2006 compared to the Nmr treatment. There was little difference in $\mathrm{N}$ loss between $\mathrm{Nmr}+\mathrm{C}$ and $\mathrm{Nmr}+\mathrm{CS}$ treatments in 2005. However, in $2006 \mathrm{~N}$ loss under the $\mathrm{Nmr}+\mathrm{CS}$ treatment increased by $19 \%$ in contrast to the $\mathrm{Nmr}+\mathrm{C}$ treatment.

\section{Discussion}

Excessive $\mathrm{N}$ in the soil-plant system is associated with environmental hazards (Crews and Peoples 2005; Olfs et al. 2005). Synchronizing cucumber $N$ demand with 
Fig. 7 Soil $\mathrm{N}_{\min }$ content to a soil depth of $0.9 \mathrm{~m}$ with or without sweet corn as catch crop in the summer fallow period in the greenhouse cucumber cropping system in 2005 and 2006. Bars represent $\mathrm{SD}$ of means with three replicates per treatment
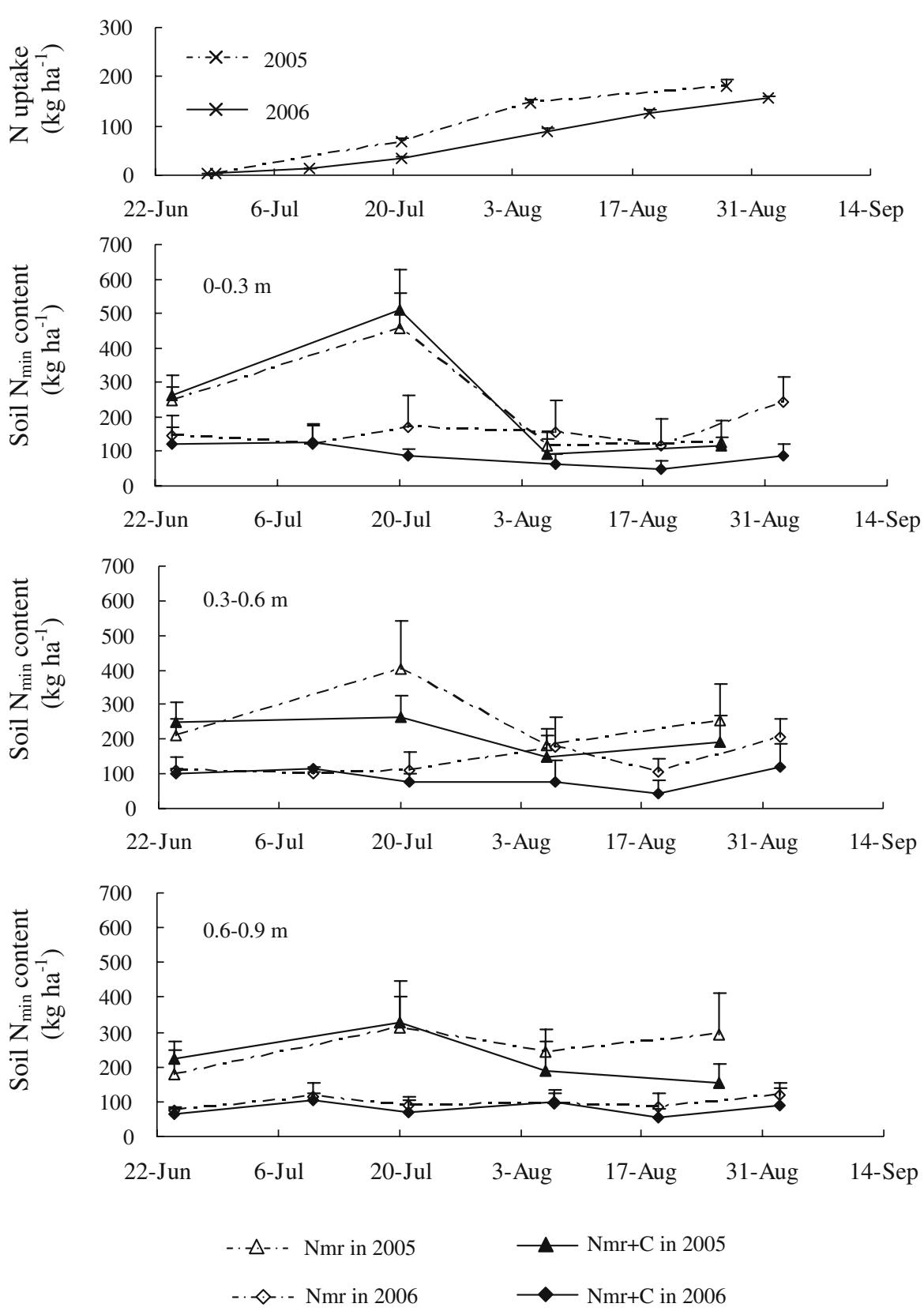

critical nutrient supply at different growth stages is the key objective to solve the conflict between high yields and environmental protection. The effects of $\mathrm{N}$ fertilization practice on cucumber yield have been discussed in detail by Guo et al. (2008). Compared to traditional $\mathrm{N}$ management, the fertilizer $\mathrm{N}$ input was reduced by $53 \%$ by means of root zone $\mathrm{N}$ management (Nmr), taking into account soil and environmental $\mathrm{N}$ supply and $\mathrm{N}$ uptake by cucumber. In our experiments, root zone $\mathrm{N}$ management was a very efficient and direct method of lowering $\mathrm{N}$ losses by $44 \%$ and $45 \%$ in 2005 and 2006, respectively. However, at least $386 \mathrm{~kg} \mathrm{~N} \mathrm{ha}^{-1}$ (not including soil $\mathrm{N}$ mineralization) per season was lost from the plant-soil system even with lowered $\mathrm{N}$ inputs. The high $\mathrm{N}_{\text {min }}$ buffer of $200 \mathrm{~kg} \mathrm{~N}^{-1}$ for cucumber production far exceeded the ecological threshold of $90 \mathrm{~kg} \mathrm{~N} \mathrm{ha}^{-1}$ in soil (Declercq et al. 2001), which led to unavoidable nitrate leaching risk. From the results of our 2-year experiment, $200 \mathrm{~kg} \mathrm{~N} \mathrm{ha}^{-1}$ of soil $\mathrm{N}_{\text {min }}$ buffer was appropriate for the intermediate growth 
Fig. 8 Soil $\mathrm{N}_{\min }$ content

(A) and soil water content

(B) throughout the top

$1.80 \mathrm{~m}$ of the soil profile

with or without sweet corn as catch crop in the summer fallow period in the greenhouse cucumber cropping system. Bars represent SD of means with three replicates per treatment

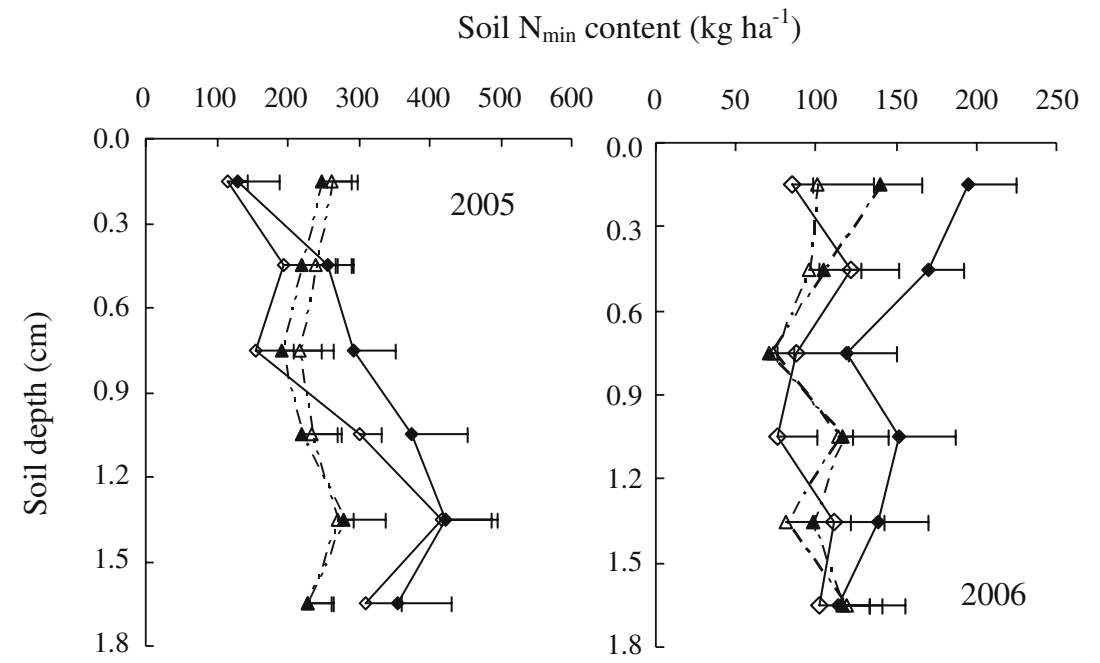

A

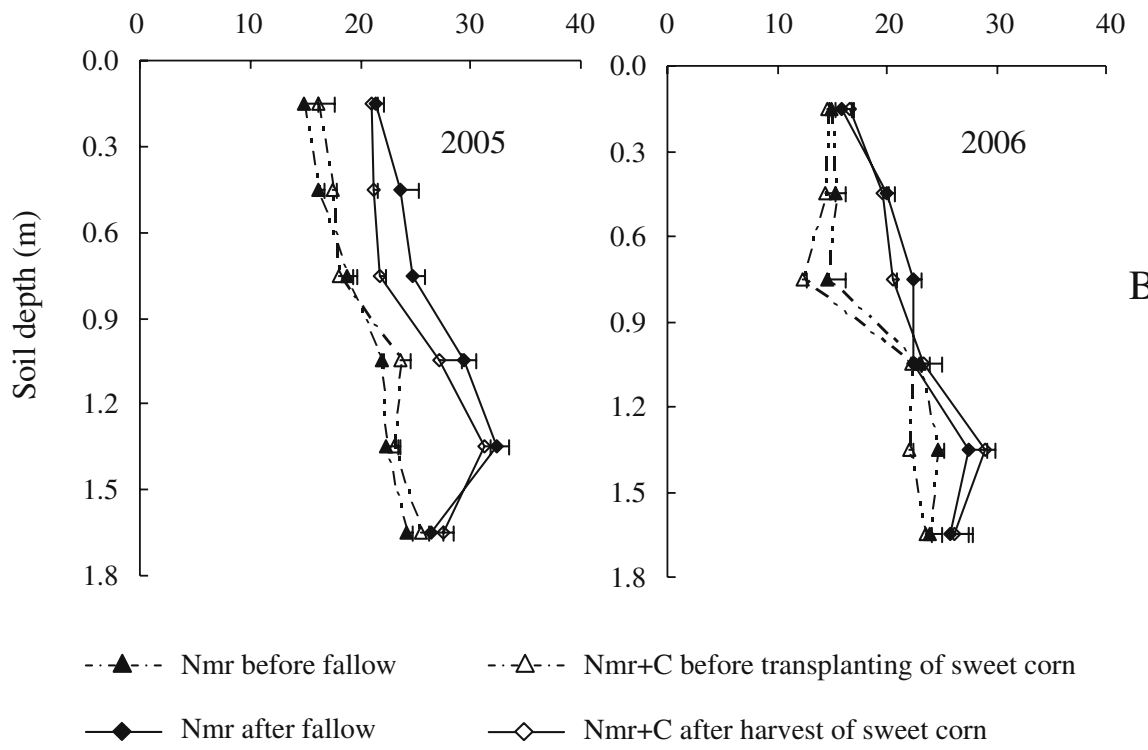

stage of cucumber, characterized by rapid $\mathrm{N}$ uptake and dry matter accumulation in both the WS and AW seasons (Guo et al. 2008). However, $200 \mathrm{~kg} \mathrm{~N}^{-1}$ of soil $\mathrm{N}_{\text {min }}$ buffer was relatively high in the early and later growth stages, characterized by slow $\mathrm{N}$ uptake and dry matter accumulation (Guo et al. 2008), especially in the later growth stages during the AW season with low temperatures. The $\mathrm{N}_{\min }$ buffer should therefore be adjusted during the different cucumber growth stages according to $\mathrm{N}$ uptake and dry matter accumulation.

$\mathrm{N}$ leaching outside the growing season may appear to be completely outside the control of the grower because of high residual $\mathrm{N}_{\min }$ and high precipitation typical of the summer fallow season on the North China Plain. To prevent leaching of nitrogen after harvest and potential contamination of groundwater, the nitrogen used for the $\mathrm{N}_{\text {min }}$ buffer can be removed from the soil by growing a cover crop of another species (Strock et al. 2004; Weinert et al. 2002).

Ju et al. (2007) demonstrated the high risk of nitrate leaching in the summer season and suggested that deep-rooted species such as corn can be used as a catch crop to intercept soil nitrate deep in the soil profile to control nitrate leaching. Integrated $\mathrm{N}$ management with catch crops could maintain low residual $\mathrm{N}_{\text {min }}$ at transplanting of succeeding vegetable crops to protect 
Table $5 \mathrm{~N}$ balance in the top $0.3 \mathrm{~m}$ of the soil profile under different $\mathrm{N}$ treatments in greenhouse cucumber experiments in Changping, Beijing suburbs from 2005 to $2006\left(\mathrm{~kg} \mathrm{~N}^{-1}\right)$

\begin{tabular}{|c|c|c|c|c|c|c|c|c|c|c|c|c|c|}
\hline \multirow[t]{2}{*}{ Component } & & \multicolumn{6}{|l|}{2005} & \multicolumn{6}{|l|}{2006} \\
\hline & & $\mathrm{N} 00^{\mathrm{a}}$ & $\mathrm{Nm} 0$ & $\mathrm{Nmt}$ & $\mathrm{Nmr}$ & $\mathrm{Nmr}+\mathrm{C}$ & $\mathrm{Nmr}+\mathrm{CS}$ & N00 & $\mathrm{Nm} 0$ & $\mathrm{Nmt}$ & $\mathrm{Nmr}$ & $\mathrm{Nmr}+\mathrm{C}$ & $\mathrm{Nmr}+\mathrm{CS}$ \\
\hline \multirow[t]{4}{*}{$\mathrm{N}$ inputs } & Total & 254 & 1,125 & 2,510 & 1,682 & 1,682 & 1,682 & 100 & 524 & 1,886 & 1,263 & 1,265 & 1,376 \\
\hline & $\begin{array}{l}\mathrm{N}_{\text {min }} \text { before } \\
\text { transplanting }\end{array}$ & 254 & 254 & 254 & 254 & 254 & 254 & 100 & 173 & 279 & 283 & 285 & 396 \\
\hline & Manure N & 0 & 871 & 871 & 871 & 871 & 871 & 0 & 351 & 351 & 351 & 351 & 351 \\
\hline & Chemical $\mathrm{N}$ & 0 & 0 & 1,385 & 557 & 557 & 557 & 0 & 0 & 1,256 & 629 & 629 & 629 \\
\hline \multirow[t]{3}{*}{$\mathrm{N}$ outputs } & Total & 422 & 548 & 831 & 743 & 946 & 953 & 364 & 416 & 814 & 676 & 792 & 790 \\
\hline & $\mathrm{N}$ uptake & 362 & 455 & 437 & 476 & 659 & 645 & 339 & 386 & 505 & 503 & 622 & 649 \\
\hline & $\begin{array}{c}\mathrm{N}_{\text {min }} \text { after } \\
\text { harvest }\end{array}$ & 60 & 93 & 394 & 267 & 287 & 308 & 25 & 30 & 309 & 173 & 170 & 141 \\
\hline $\mathrm{N}$ balance & & -168 & 577 & 1,679 & 939 & 736 & 729 & -264 & 108 & 1,072 & 587 & 473 & 586 \\
\hline
\end{tabular}

${ }^{\mathrm{a}} \mathrm{N} 00, \mathrm{Nm} 0, \mathrm{Nmt}, \mathrm{Nmr}, \mathrm{CNmr}$ and $\mathrm{CNmr}+\mathrm{C}$ denote control, $\mathrm{N}$ from organic manure, conventional $\mathrm{N}$ management and root zone $\mathrm{N}$ management, reduced-N management with sweet corn as catch crop and root zone $\mathrm{N}$ management with sweet corn as catch crop and with residue incorporation after the sweet corn harvest.

the environment from pollution in intensive greenhouse cropping systems. Furthermore, deep-rooted cover crops may help alleviate the effects of soil compaction and succeeding crops may benefit from root channels left by the decomposing roots of cover crops as demonstrated in soybean cropping systems following cover crops (Williams and Weil 2004). A number of experiments were conducted to compare the suitability of different crop species as catch crops under greenhouse conditions. The crops studied were sweet corn, hairy vetch and Chinese onion. The results indicate that sweet corn was the most suitable catch crop, not only for depleting soil nitrogen, but also because of farmer preference and economic performance (data not shown). In our experiment apparent $\mathrm{N}$ losses were further reduced by $19-22 \%$ by using sweet corn as a summer catch crop based on reduced $\mathrm{N}$ inputs with no significant reduction in the yield of succeeding cucumber. Depletion of $\mathrm{N}_{\min }$ in the top $0.9 \mathrm{~m}$ of the soil profile was found to be associated with the root growth of sweet corn. Kristensen and Thorup-Kristensen (2004a) reported that soil $\mathrm{N}$ depletion by catch crop species was highly correlated with their rooting depth but there was little correlation with root density. According to Wiesler and Horst (1994), sweet corn roots may penetrate the soil to a depth of $1.5 \mathrm{~m}$. However, Kristensen and Thorup-Kristensen (2004b) observed shallow rooting $(0.3 \mathrm{~m})$ by sweet corn in minirhizotrons and they attributed the differences in their results to relatively low temperatures in spring and summer. In our experiment sweet corn rooting depth approached $1.1 \mathrm{~m}$, which was in accordance with the results of Ren (2003) at Dongbeiwang in the Beijing suburbs. This was likely adequate to deplete soil $\mathrm{N}_{\text {min }}$ below $0.3 \mathrm{~m}$ in the soil profile. Kristensen and Thorup-Kristensen (2004b) found $\mathrm{N}$ utilization efficiencies of sweet corn at 0.2 , $0.4,0.6$ and $0.8 \mathrm{~m}$ depths of up to $23 \%, 6 \%, 3 \%$ and $0.8 \%$ in a 6-day study using $\mathrm{NO}_{3}{ }^{-}{ }^{15} \mathrm{~N}$ isotope techniques. However, we observed differences between 2005 and 2006 in the pattern of scavenging by sweet corn in the top $0.3 \mathrm{~m}$ of the soil profile. Low $\mathrm{N}$ availability to sweet corn may explain the evident exhaustion of $\mathrm{N}$ in the root zone in 2006. Although Thorup-Kristensen et al. (2003) included adequate $\mathrm{N}$ supply to increase the growth and $\mathrm{N}$ uptake by the cover crop over a short time period, in our experiment strong $\mathrm{N}$ mineralization due to high $\mathrm{N}$ inputs in 2005 may have masked the effects of $\mathrm{N}$ uptake by sweet corn on soil $\mathrm{N}_{\text {min }}$ depletion in the top $0.3 \mathrm{~m}$ of the soil profile.

Cover crops reduce the potential for $\mathrm{NO}_{3}$ leaching by (1) taking up and storing soil active $\mathrm{N}$ in plant tissues during the leaching-prone fallow period with heavy precipitation during soil water recharge and (2) absorbing and transpiring water and lessening water percolation (Weinert et al. 2002; Thorup-Kristensen et al. 2003). In the present study no significant difference in water content was found between the $\mathrm{Nmr}$ and $\mathrm{Nmr}+\mathrm{C}$ treatments after sweet corn cropping. Changing soil water flux is a complex process and we did not measure drainage under the different treatments in our experi- 
ment. It is therefore difficult to explain $\mathrm{N}$ movement on the basis of soil water flux. The amount of $\mathrm{N}$ taken up by sweet corn reached to $154-187 \mathrm{~kg} \mathrm{ha}^{-1}$. However, compared to the fallow treatment a reduction of 303$333 \mathrm{~kg} \mathrm{~N} \mathrm{ha}{ }^{-1}$ in the $0-1.8 \mathrm{~m}$ deep soil zone was achieved by sweet corn cropping. This raises the question of whether sweet corn retains more $\mathrm{N}$ in organic form in the soil by root activity compared to fallow conditions. Parkin et al. (2006) speculated that using living rye plants as a winter cover crop may have increased immobilization of $\mathrm{N}$ in the organic $\mathrm{N}$ pools. However, the amounts by which $\mathrm{N}$ loss calculated by the difference between $\mathrm{N}$ inputs and $\mathrm{N}$ outputs under the $\mathrm{Nmr}+\mathrm{C}$ treatment were reduced were 203 and $114 \mathrm{~kg} \mathrm{ha}^{-1}$, respectively. Soil organic N mineralization, which was not considered as an $\mathrm{N}$ input factor, may partly account for the differences that occur using the different methods of calculation. Substantial soil organic $\mathrm{N}$ mineralization may occur during the fallow period because of high summer temperatures. Overfertilization can lead to greater release of $\mathrm{N}$ from unavailable forms (Stevens et al. 2005) and this may be responsible for a large proportion of the increase in $\mathrm{N}_{\text {min }}$ in the top $1.8 \mathrm{~m}$ of the soil profile in the Nmt treatment.

Cover crops are used to reduce $\mathrm{N}$ leaching losses from the soil and also to improve the $\mathrm{N}$ nutrition of subsequent crops. Some risk of inadequate nitrogen supply to succeeding crops might occur if soil $\mathrm{N}_{\min }$ in the root zone were depleted and nitrogen fertilizer recommendations would increase due to low $\mathrm{N}_{\min }$ in the root zone, an unexpected effect in cover cropping systems. One effect of cover crops on the nitrogen nutrition of the succeeding crop is mineralization or immobilization caused by the decomposition of the plant residues in the soil (Thorup-Kristensen 1993). Immobilization of nitrogen by the catch crop residues is usually regarded as a disadvantage of the system because it makes soil $\mathrm{N}$ unavailable to the succeeding crop (Jensen 1991). However, in greenhouse cucumber cropping systems soil $\mathrm{N}$ was vulnerable to leaching about 40 days after transplanting because of the chicken manure application, high residual $\mathrm{N}_{\min }$, poor root growth and frequent irrigation. $\mathrm{N}$ immobilization by sweet corn straw during this period was expected to reduce the risk of nitrogen leaching. However, in our experiment no evident effect of sweet corn residues on soil $\mathrm{N}_{\text {min }}$ content was observed because the same $\mathrm{N}$ topdressing was applied as in the Nmr treatment. In future studies, therefore, the recommended $\mathrm{N}$ applica- tion rate should be calculated by taking account of mineralization by sweet corn residues which may replace part of the urea fertilizer nitrogen. In addition, cucumber residues, the $\mathrm{N}$ removal of which accounted for almost half of total $\mathrm{N}$ uptake, were removed from the greenhouse to protect subsequent cucumber crops from disease. If the residues are co-composted with manure and then applied as basal fertilizer with catch crop residues this may provide a more effective means of contributing to the $\mathrm{N}$ nutrition of subsequent vegetable crops.

\section{Conclusions}

Reduced $\mathrm{N}$ input was an efficient tool to reduce the risk of $\mathrm{N}$ losses in an intensive greenhouse cropping system. Based on recommended $\mathrm{N}$ fertilizer management, $\mathrm{N}$ losses were further reduced by growing sweet corn as a summer catch crop with no significant decrease in yield of cucumber fruits. Sweet corn can therefore be introduced as a supplementary biological $\mathrm{N}$ management tool to minimize $\mathrm{N}$ leaching losses in greenhouse cucumber cropping systems. Incorporation of sweet corn residues had little effect on lowering $\mathrm{N}$ loss compared to the treatment without residue incorporation. The change in soil $\mathrm{N}_{\text {min }}$ resulting from residue incorporation was due to a masking effect of $\mathrm{N}$ topdressing that can occur in field experiments. Appropriate adjustment of the recommended $\mathrm{N}$ application rate would therefore be advisable.

Acknowledgments We are grateful to the National Natural Science Foundation of China (Project 30671236) and the key projects of the Chinese Ministry of Science and Technology (2006BAD17B03 and 2006BAD17B07) for financial supports.

\section{References}

Addiscott TM, Bailey NJ, Bland GJ, Whitmore AP (1991) Farming, fertilizers and the nitrate problems. CAB International, Wallingford, Oxon, p 176

Cabrera ML, Chiang SC (1994) Water content effect on denitrification and ammonia volatilization in poultry litter. Soil Sci Soc Am J 58:811-816

Chen Q, Zhang XS, Zhang HY, Christie P, Li XL, Horlacher D et al (2004) Evaluation of current fertilizer practice and soil fertility in vegetable production in the Beijing region. Nutr Cycl Agroecosyst 69:51-58

Chen Q, Zhang HY, Li XL, Christie P, Horlacher D, Liebig HP (2005) Use of a modified N-expert system for vegetable production in the Beijing region. J Plant Nutr 28:475-487 
Crews TE, Peoples MB (2005) Can the synchrony of nitrogen supply and crop demand be improved in legume and fertilizer-based agroecosystems? A review. Nutr Cycl Agroecosyst 72:101-120

Declercq P, Salomez J, Hofman G (2001) Environmental pressures and national environmental legislation with respect to nutrient management in Belgium. In: Declercq $\mathrm{P}$, Gertsis AC, Hofman G, Jarvis SC, Neeteson JJ, Sinabell F (eds) Nutrient management legislation in European Countries. Wageningen, The Netherlands, pp 56-77

Fox RH, Piekielek WP, MacNeal KE (1996) Estimating ammonia volatilization losses from urea fertilizers using a simplified micrometeorological sampler. Soil Sci Soc Am J 60:596-601

Gollany HT, Molina JE, Clapp CE, Allmaras RR, Layese MF, Baker JM et al (2004) Nitrogen leaching and denitrification in continuous corn as related to residue management and nitrogen fertilization. Environ Manage 33(Suppl 1): S289-S298

Guo RY, Li XL, Christie P, Chen Q, Zhang FS (2008) Seasonal temperatures have more influence than nitrogen fertilizer rates on cucumber yield and nitrogen uptake in a double cropping system. Environ Pollut 151:443-451

He YH, Cheng ZQ, Guan CH (2003) Relationship between long-term changes of summer rainfall in North China and sea surface temperature over South China sea. J Trop Oceanogr 22:1-8 (in Chinese with English summary)

He FF, Chen Q, Jiang RF, Chen XP, Zhang FS (2007) Yield and nitrogen balance of greenhouse tomato (Lycopersicum esculentum Mill.) with conventional and site-specific nitrogen management in Northern China. Nutr Cycl Agroecosyst 77:1-14

Houba VJG, Novozamsky I, Huybregts AWM, Van der Lee JJ (1986) Comparison of soil extractions by $0.01 \mathrm{M} \mathrm{CaCl}_{2}$, by EUF and by some conventional extraction procedures. Plant Soil 96:433-437

Jensen ES (1991) Nitrogen accumulation and residual effects of nitrogen catch crops. Acta Agric Scand 41:333-344

Ju XT, Gao Q, Christie P, Zhang FS (2007) Interception of residual nitrate from a calcareous alluvial soil profile on the North China Plain by deep-rooted crops: ${ }^{15} \mathrm{~N}$ tracer study. Environ Pollut 146:534-542

Kotsiras A, Olympios CM, Drosopoulos J, Passam HC (2002) Effects of nitrogen form and concentration on the distribution of ions within cucumber fruits. Sci Hortic (Amsterdam) 95:175-183

Kristensen HL, Thorup-Kristensen K (2004a) Root growth and nitrate uptake of three different catch crops in deep soil layers. Soil Sci Soc Am J 68:529-537

Kristensen HL, Thorup-Kristensen K (2004b) Uptake of ${ }^{15} \mathrm{~N}$ labeled nitrate by root systems of sweet corn, carrot and white cabbage from 0.2 to 2.5 meters depth. Plant Soil 265:93-100

Kuo S, Jellum EJ (2002) Influence of winter cover crop and residue management on soil nitrogen availability and corn. Agron J 94:501-508

Kuo S, Jellum EJ, Sainju UM (1995) The effect of winter cover cropping on soil and water quality. In: Proceedings of the Western Nutrient Management Conference, Salt Lake City, UT, pp 56-64

Logsdon D, Kaspar TC, Meek DW, Prueger JH (2002) Nitrate leaching as influenced by cover crops in large soil monoliths. Agron J 94:807-814

Mayfield JL, Simonne EH, Mitchell CC, Sibley JL, Boozer RT, Vinson EL (2002) Effect of current fertilization practices on nutritional status of double-cropped tomato and cucumber produced with plasticulture. J Plant Nutr 25:1-15

Meisinger JJ, Hargrove WL, Mikkelsen RL, Williams JR, Benson VW (1991) Effects of cover crops on groundwater quality. In: Hargrove WL (ed) Cover crops for clean water. Soil Water Conservation Society, Ankeny, IA, pp 57-68

Olfs HW, Blankenau K, Brentrup F, Jasper J, Link A, Lammel J (2005) Soil- and plant-based nitrogen - fertilizer recommendations in arable farming. J Plant Nutr Soil Sci 168:414-431

Parkin TB, Kaspar TC, Singer JW (2006) Cover crop effects on the fate of $\mathrm{N}$ following soil application of swine manure. Plant Soil 289:141-152

Patil SK, Singh U, Singh VP, Mishra VN, Das RO, Henao J (2001) Nitrogen dynamics and crop growth on an Alfisol and a Vertisol under a direct-seeded rainfed lowland ricebased system. Field Crops Res 70:185-199

Pei XB (2002) Studies on regularity of water and solute transfer of cucumber growing in solar greenhouse. PhD dissertation, China Agricultural University, Beijing, China, 79 pp (in Chinese with English summary)

Powlson DS (1993) Understanding the soil nitrogen cycle. Soil Use Manage 9:86-94

Ramos C, Agut A, Lidon AL (2002) Nitrate leaching in important crops of the Valencian Community region (Spain). Environ Pollut 118:215-223

Ren ZH (2003) Nitrate accumulation and related control strategies in the open-field vegetable production of Beijing suburb. MSc dissertation, China Agricultural University, Beijing, China, 53 pp (In Chinese with English summary)

Sainju UM, Singh BP (1997) cover crops for sustainable agricultural systems: Influence on soil properties, water quality, and crop yields. HortScience 32:21-28

Snapp SS, Swinton SM, Labarta R, Mutch D, Black JR, Leep R, Nyiraneza J, O’Neil K (2005) Evaluating cover crops for benefits, costs and performance within cropping system niches. Agron J 97:1-11

Stevens WB, Hoeft RG, Mulvaney RL (2005) Fate of nitrogen15 in a long-term nitrogen rate study. I. Interactions with soil nitrogen. Agron J 97:1037-1045

Strock JS, Porter PM, Russelle MP (2004) Cover cropping to reduce nitrate loss through subsurface drainage in the northern US Corn Belt. J Environ Qual 33:1010-1016

Tennant DA (1975) Test of a modified intersect method of estimating root length. Ecology 63:995-1001

Thomsen IK (2005) Nitrate leaching under spring barley is influenced by the presence of a ryegrass catch crop: Results from a lysimeter experiment. Agric Ecosyst Environ 111:21-29

Thomsen IK, Christensen BT (1999) Nitrogen conserving potential of successive ryegrass catch crops in continuous spring barley. Soil Use Manage 15:195-200

Thorup-Kristensen K (1993) The effect of nitrogen catch crops on the nitrogen nutrition of a succeeding crop. I. Effects through mineralization and pre-emptive competition. Acta Agric Scand B Soil Plant Sci 43:74-81

Thorup-Kristensen K (2006) Root growth and nitrogen uptake of carrot, early cabbage, onion and lettuce following a range of green manures. Soil Use Manage 22:29-38

Thorup-Kristensen K, Magid J, Jensen LS (2003) Catch crops and green manures as biological tools in nitrogen management in temperate zones. Adv Agron 79:227-302 
Verma P, George KV, Singh HV, Singh RN (2007) Modeling cadmium accumulation in radish, carrot, spinach and cabbage. Appl Math Model 31:1652-1661

Wang Q, Li Y, Klassen W (2005) Influence of summer cover crops on conservation of soil water and nutrients in a subtropical area. J Soil Water Conserv 60(1):58-63

Weaver JE, Bruner WE (1927) Root development of vegetable crops. McGraw-Hill, New York, p 351

Weinert TL, Pan WL, Moneymaker MR, Santo GS, Stevens RG (2002) Nitrogen recycling by nonleguminous winter cover crops to reduce leaching in potato rotations. Agron J 94:365-372
Wiesler F, Horst WJ (1994) Root growth and nitrate utilization of maize cultivars under field conditions. Plant Soil 163:267-277

Williams SM, Weil RR (2004) Crop cover root channels may alleviate soil compaction effects on soybean crop. Soil Sci Soc Am J 68:1403-1409

Zhang WL, Tian ZX, Zhang N, Li XQ (1996) Nitrate pollution of groundwater in northern China. Agric Ecosyst Environ 59:223-231

Zhu JH, Li XL, Christie P, Li JL (2005) Environmental implications of low nitrogen use efficiency in excessively fertilized hot pepper (Capsicum frutescens L.) cropping systems. Agric Ecosyst Environ 111:70-80 